\title{
INSECTICIDAL ACTIVITY OF LINOLEIC ACID AGAINST SPODOPTERA LITTORALIS (BOISD.)
}

\author{
YOUSEF, HEBA ${ }^{1,{ }^{*}}$, SAHEIR F. EL-LAKWAH ${ }^{1}$ and YASMEIN A. EL SAYED ${ }^{2}$ \\ 1. Department of Pest Physiology, Plant Protection Research Institute, ARC, Dokki, \\ Giza, Egypt. E-mail: hebayousef 2004@yahoo.com \\ 2. Biological Control Unit, Plant Protection Research Institute, ARC, Dokki, Giza, \\ Egypt. \\ * Author for correspondence and reprint requests
}

(Manuscript received 30 October 2012)

\begin{abstract}
Toxicity and reduction in larval body weight studies were performed to determine the activity of linoleic acid against the $2^{\text {nd }}$ and $4^{\text {th }}$ instar larvae of Spodoptera littoralis. The tested fatty acid showed high significant toxic effect on the two instars, with $\mathrm{LC}_{50}$ values of 4.78 and $9.11 \mathrm{~g} / 100 \mathrm{~mL}$, respectively. Linoleic acid resulted in significant larval weight reduction. The percentage of larval body weight reduction against the $4^{\text {th }}$ instar was higher than that of the $2^{\text {nd }}$ instar larvae.
\end{abstract}

Key words: Linoleic Acid, Insecticidal Activity, Spodoptera littoralis.

\section{INTRODUCTION}

The Egyptian cotton leafworm $S$. littoralis is considered as the major pest in a wide range of cultivation including cotton, corn, soybeans, peanuts, and vegetables. This pest is not only widely spread in Egypt but also in other Middle East countries in addition to temperate zones in Asia and Africa (Salama et. al., 1990).

Great efforts have been made to control $S$. littoralis chemically. The extensive use of these synthetic pesticides has given rise to problems such as residuals toxicity (pollution), pesticide resistance and harmful effects on beneficial insects, such as natural enemies, honey bees and beneficial birds.

For the above mentioned reasons, the general trends in last three decade were the substitution of synthetic pesticides by natural products, which were used as crude or oil extracts.

Recently, Farag et. al.(2011) found that fatty acids and their esters were not only the main constituents of essential oil from the ripe fruits of Melia azedarach, but also mainly responsible for the insecticidal and growth inhibition activity against $S$. littoralis.

Ramsewak et. al.(2001) reported the insecticidal and insectistatic activities of linoleic acid against Aedes aegyptii (Diptera: Culicidae), Helicoverpa zea (Lepidoptera: 
Noctuidae), Lymantria dispar (Lepidoptera: Lymantriidae), Malacosoma disstria (Lepidoptera: Lasiocampidae), and Orgyia leucostigma (Lepidoptera: Lymantriidae).

The aim of the present work is to study the insecticidal activity of linoleic acid against the $2^{\text {nd }}$ and $4^{\text {th }}$ instars larvae of $S$. littoralis. The insecticidal activity of linoleic acid against $S$. littoralis is reported for first time in the present work.

\section{MATERIAL AND METHODS}

\section{Chemicals}

Linoleic acid was purchased from ABCR GmbH \& Co KG, Im Schlehert 10, 76187 Karlsruhe, Germany.

\section{Strain of cotton leafworm S. littoralis}

The $S$. littoralis strain was obtained from the Faculty of Agriculture, Cairo University, Egypt, and was reared in the laboratory of the Physiology Department, Plant Protection Research Institute, Agricultural Research Center, Giza, Egypt, as described by El-Defrawi et. al.(1964), under constant laboratory conditions at (25 \pm 1 ) ${ }^{\circ} \mathrm{C},(70 \pm 5) \%$ relative humidity and a photoperiod of $16 \mathrm{~h}: 8 \mathrm{~h}(\mathrm{~L}: \mathrm{D})$. Adults were fed with a $15 \%$ solution of honey. Filter paper was provided as an oviposition substrate, and it was replaced periodically.

\section{Toxicity assay}

The leaf-dipping technique, similar to that described by Tabashink et. al. (1987), was used to evaluate the toxicity of linoleic acid against the $2^{\text {nd }}$ and $4^{\text {th }}$ instar larvae using concentrations of $1.25,2.50,5.00,10.00$, and $20.00 \mathrm{~g} / 100 \mathrm{~mL}$ of linoleic acid in acetone. Eight castor leaves were dipped for $5 \mathrm{~s}$ in each solution and then the treated leaves were left for natural air-drying and were distributed in four jars (2 leaves/jar). Ten of both $2^{\text {nd }}$ and $4^{\text {th }}$ instar larvae were allowed to feed on treated leaves for $48 \mathrm{~h}$, and then larvae were fed on untreated leaves for $24 \mathrm{~h}$. Four replicates of ten larvae were fed on acetone-treated leaves for $72 \mathrm{~h}$ to serve as control. Larval weight and mortality were recorded after $72 \mathrm{~h}$.

\section{Statistical analysis}

Mortality was calculated using the Abbott formula (Abbott, 1925) and subjected to probit analysis according to Finney (1971).

The toxic and larval weight reduction effect of linoleic acid were analysed using ANOVA and Duncan's multiple range tests (ANOVA of arcsine square root transformed percentages). Differences between the treatments were determined by Tukey's multiple range test $(P<0.05)$ (Snedecor and Cochran, 1989). 


\section{RESULTS AND DISCUSSION}

Data represented in (Table I) revealed that the highest toxicity rates were $87.5 \%$ and $70 \%$ mortality with the $2^{\text {nd }}$ and $4^{\text {th }}$ instars, respectively were obtained at the highest concentration of $20 \mathrm{~g} / 100 \mathrm{~mL}$. Linoleic acid exhibited high toxicity rate with concentration dependent. The results indicated that $\mathrm{LC}_{50}$ values were 4.78 and $9.11 \mathrm{~g} / 100 \mathrm{~mL}$ with the $2^{\text {nd }}$ and $4^{\text {th }}$ instar larvae, respectively.

As shown in (Table II), the percentages of larval weight reduction in $S$. littoralis treated with linoleic acid increase gradually with the increasing of concentrations against the $2^{\text {nd }}$ and $4^{\text {th }}$ instar larvae. Larval weight reduction percentages were $15.7,34.95,50.18,66.68,69.5 \%$ and 55.49, 59.15, 62.47, 69.12, $73.16 \%$ with $2^{\text {nd }}$ and $4^{\text {th }}$ instar larvae, respectively at concentrations of $1.25,2.5,5$, $10,20 \mathrm{~g} / 100 \mathrm{~mL}$ respectively. In the fact, the reduction in larval body weight was positively correlated with linoleic acid concentration; the same observation was recorded with both $2^{\text {nd }}$ and $4^{\text {th }}$ instars. Approximately, the highest decrease of larval body weight recorded at concentration of $20 \mathrm{~g} / 100 \mathrm{~mL}$ against the $4^{\text {th }}$ instar larvae.

Our results about the insecticidal effectiveness of linoleic acid were in agreement with those obtained by Farlane and henneberry (1965) who found that, growth of the cricket, Gryllodes sigillatus (Walk.), was inhibited by fatty acids and their methyl esters. Similar results were reported by Juárez and Napolitano (2000). While, Andrews and Miskus (1972) mentioned that larvae and pupae of the western spruce budworm (Choristoneura occidentalis) differed in their response to applied oleic or linoleic acid or sweet almond oil. The acids were more toxic than the oils by factors of 15 for larvae and 3 for pupae. Fatty acids were found to exert profound physiological control over conidium development. Palmitoleic acid, linoleic acid and linolenic acid were toxic to conidia over a wide range of concentrations (Kerwin, 1982). Abdul Rahuman and Venkatesan (2008) found that oleic and linoleic acids were quite potent toxic against the 4th larvae of Aedes aegypti L., Anopheles stephensi Liston and Culex quinquefasciatus Say.

Plant fatty acids showed insecticidal activity against insects. Farag et. al. (2011) found that fatty acids and their esters were not only the main constituents of essential oil from the ripe fruits of $M$. azedarach, but also mainly responsible for the insecticidal and growth inhibition activity against $S$. littoralis. The potency of botanical 
fatty acids was reported by Abdallah et. al.(2009) against Aphis craccivora. Tare and Sharma (1991) compared the larvicidal properties of different fatty acids constituents against Aedes aegypti and found that oleic acid was the most effective one. Barakat et. al. (2004) reported that the ethanol and hexane crude extracts of Cassia fistula (L.) reduced pupation, egg production, and hatchability, and increased percent sterility; the dominant constituents were fatty acids, linoleic acid, hexadecanoic acid, and octadecanoic acid, and their alkyl esters. linolenic acid and linoleic acid were also found to have insectistatic and insecticidal activities against Spodoptera frugiperda as described by Ramos-López et. al. (2012).

In conclusion, linoleic acid could be considered as new effective insecticide for the cotton leafworm, S. littoralis control. 
Table I. Toxic effect and LC50 of linoleic acid against 2nd and 4th instar larvae of S. littoralis.

\begin{tabular}{|c|c|c|}
\hline \multirow{2}{*}{ Treatment } & \multicolumn{2}{|c|}{ Corrected mortality (\%) \pm SD } \\
\cline { 2 - 3 } & $2^{\text {nd }}$ instar & $4^{\text {th }}$ instar \\
\hline Control & $0.00 \pm 0.00$ & $0.00 \pm 0.00$ \\
\hline $1.25[\mathrm{~g} / 100 \mathrm{~mL}]$ & $15.00 \pm 0.10$ & $10.00 \pm 0.40$ \\
\hline $2.50[\mathrm{~g} / 100 \mathrm{~mL}]$ & $37.50 \pm 0.01$ & $25.00 \pm 0.05$ \\
\hline $5.00[\mathrm{~g} / 100 \mathrm{~mL}]$ & $45.00 \pm 0.00$ & $37.50 \pm 0.17$ \\
\hline $10.00[\mathrm{~g} / 100 \mathrm{~mL}]$ & $70.00 \pm 0.20$ & $47.50 \pm 0.10$ \\
\hline $20.00[\mathrm{~g} / 100 \mathrm{~mL}]$ & $87.50 \pm 0.03$ & $70.00 \pm 0.01$ \\
\hline LC 50 & 4.78 & 9.11 \\
\hline$F$ & $15984.96^{* * *}$ & $24316.41^{* * *}$ \\
\hline LSD & 0.72 & 0.33 \\
\hline
\end{tabular}

Values in the same column are all significantly different (ANOVA, Duncan's multiple range test, $P<0.05)$.

SD: is standard deviation.

***: highly significant effect.

Table II. Effect of linoleic acid on mean larval weight (M. W.) and weight reduction (W. R.) of the 2 nd and 4th instar larvae $S$. littoralis.

\begin{tabular}{|c|c|c|c|c|}
\hline \multirow{3}{*}{ Treatment } & \multicolumn{4}{|c|}{ Mean larval weight (mg) and weight reduction (\%) } \\
\hline & \multicolumn{2}{|c|}{$2^{\text {nd }}$ instar } & \multicolumn{2}{|c|}{$4^{\text {th }}$ instar } \\
\hline & M. W. [mg] & W. R. (\%) & M. W. $[\mathrm{mg}]$ & W. R. $(\%)$ \\
\hline Control & 18.91 & 0.00 & 59.80 & 0.00 \\
\hline $1.25[\mathrm{~g} / 100 \mathrm{~mL}]$ & 15.91 & 15.70 & 26.66 & 55.49 \\
\hline $2.50[\mathrm{~g} / 100 \mathrm{~mL}]$ & 12.30 & 34.95 & 24.46 & 59.15 \\
\hline $5.00[\mathrm{~g} / 100 \mathrm{~mL}]$ & 9.42 & 50.18 & 22.48 & 62.47 \\
\hline $10.00[\mathrm{~g} / 100 \mathrm{~mL}]$ & 6.30 & 66.68 & 18.50 & 69.12 \\
\hline $20.00[\mathrm{~g} / 100 \mathrm{~mL}]$ & 5.76 & 69.50 & 16.11 & 73.16 \\
\hline$F$ & \multicolumn{2}{|c|}{$178499.00 * * *$} & \multicolumn{2}{|c|}{$13953.70^{* * *}$} \\
\hline LSD & \multicolumn{2}{|c|}{0.17} & \multicolumn{2}{|c|}{0.19} \\
\hline
\end{tabular}

Values in the same column are all significantly different (ANOVA, Duncan's multiple range test, $P<0.05$ ).

Weight Reduction $(\%)=[($ Control - M. W. $) /$ Control $] .100$.

$* * *$ : highly significant effect. 


\section{REFERENCES}

1. Abbott W. S. A. 1925. Method for computing the effectiveness of an insecticide. J. Econ. Entomol. 18, 265.

2. Abdallah A. S., A. A. Barakat, A. H. M. Badawy, A. F. Mansour and M. M. M. Solimann. 2009. Toxicological and phytochemical studies of wild plant Halocnemon strobilacium crude extracts and their components against Aphis craccivora Koch. J. Appl. Sci. Res. 5, 699-705.

3. Abdul Rahuman A. and P. Venkatesan. 2008. Mosquito larvicidal activity of oleic and linoleic acids isolated from Citrullus colocynthis (Linn.) Schrad. Parasitol. Res. 103, 1383-1390.

4. Andrews T. L. and R. P. Miskus. 1972. Some effects of fatty acids and oils on western spruce budworm larvae and pupae. Pest. Biochem. and Physiol. 2 , 257261.

5. Barakat A. A., A. S. El-Mahy, K. Omaima, K. O. Moustafa, F. A. Mansour and K. M. El-hadek. 2004. Biological effect of Cassia fistula (L.) seeds against the cotton leafworm Spodoptera littoralis (Boisd.) with special reference to chemical constituents. Bull. Entomol. Soc. Egypt, Econ. Ser. 30, 1-14.

6. El-Defrawi M. E., A. Toppozada, N. Mansour and ZeidM. 1964. Toxicological studies on Egyptian cotton leaf worm Prodenia litura (F.). I: Suceptiblity of different larval instars to insecticides. J. Econ. Entomol. 57, 591 - 593.

7. Farag M., M. H. M. Ahmed, H. Yousef and A. A. H. Abdel-Rahman. 2011. Repellent and insecticidal activities of Melia azedarach L. against cotton leafworm Spodoptera littoralis (Boisd.). Z. Naturforsch. 66c, 129-135.

8. Farlane J. E. M. and G. O. Henneberry. 1965. Inhibition of the growth of an insect by fatty acids. J. Ins. Physiol. 11, 1247-1252.

9. Finney D. J. 1971. Probity Analysis Statistical Treatment of the Sigmoid Response Curve. Cambridge University Press, Cambridge, p. 256.

10. Juárez M. P. and R. Napolitano. 2000. Effects of organic acids on lipid synthesis and ecdysis in Triatoma infestans eggs Comp. Biochem. and Physiol. Part B: Biochem. and Mol. Biol. 125, 503-510.

11. Kerwin J. L. 1982. Chemical Control of the Germination of Asexual Spores of Entomophthora culicis, a Fungus Parasitic on Dipterans. J. Gener. Microbio. 128, 2179-2186. 
12. Ramos-López M. A., M. M. González-Chávez, N. C. Cárdenas-Ortega, M. A. ZavalaSánchez and G. S. Pérez. 2012. Activity of the main fatty acid components of the hexane leaf extract of Ricinus communis against Spodoptera frugiperda. Afri. J. Biotechnol. 11, 4274-4278.

13. Ramsewak R. S., M. G. Nair, S. Murugesan, W. J. Mattson and J. Zasada. 2001. Insecticidal fatty acids and triglycerides from Dirca palustris. J. Agri. Food Chem. 49, 5852-5856.

14. Salama H. S., S. A. Salem, F. N. Zaki and A. Shams EL-din. 1990. Comparative effectiveness of Bacillus thuringiensis and lannate against Spodoptera littoralis. J. Islam. Acad. Sci. 3, 325-329.

15. Snedecor G. W. and W. G. Cochran. 1989. Statistical Methods, $8^{\text {th }}$ ed. Iowa State University Press, Ames, Iowa.

16. Tabashink B. E., N. L. Cushing and M. W. Johnson. 1987. Diamond back moth (Lepidoptera: Plutellidae) resistance to insecticides in Hawaii: Intra-island variation and cross resistance. J. Econ. Entomol. 80, 1091-1099.

17. Tare V. and R. N. Sharma. 1991. Larvicidal activity of some tree oils and their common chemical constituents against mosquitoes. Pestic. Res. J. 3, 169-172. 


\section{النشاط السام لحمض اللينوليك ضد دودة ورق القطن}

$$
\begin{aligned}
& \text { هبه يوسف1 } 1 \text { ، سهير فيصل اللقوة } 1 \text { باسمين السيد احمد } \\
& \text { ' - قسم فسيولوجيا الافات - معرة بحوث وقايه النباتات - مركز البحوث الزراعيه - الدقى } \\
& \text { الجيزة } \\
& \text { r - وحده الدكافحه الحيويه - معهة بحوث وقايه النباتات - مركز البحوث الزراعبه - الدقى - } \\
& \text { الجبزة } \\
& \text { أجريت الدراسة فى هذا البحث بغرض تحديد نشاط حمض اللينوليك من حيث السمية }
\end{aligned}
$$

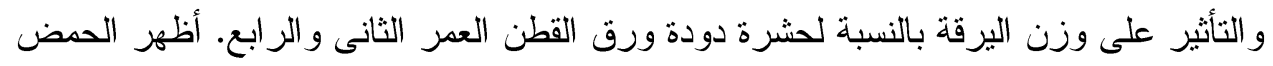

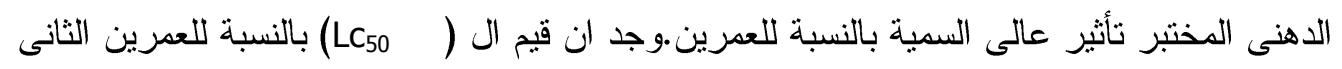

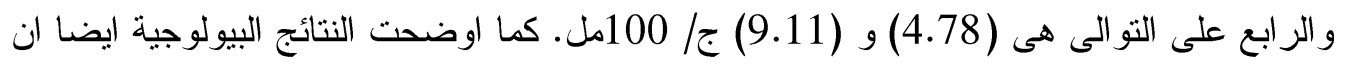

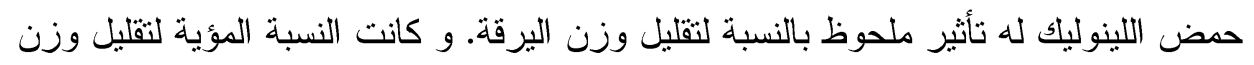

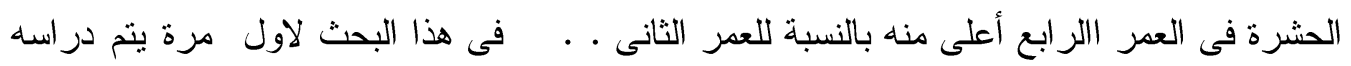

$$
\begin{aligned}
& \text { النشاط السام لحمض اللينوليك على دوده ورق القطن. }
\end{aligned}
$$

